\title{
When to stop?
}

Jon Eik Zwisler, John Larsen \& Lars F. Gram

To cite this article: Jon Eik Zwisler, John Larsen \& Lars F. Gram (2009) When to stop?, Scandinavian Journal of Primary Health Care, 27:1, 1-3, DOI: 10.1080/02813430902731233

To link to this article: https://doi.org/10.1080/02813430902731233

册 Published online: 12 Jul 2009.

Submit your article to this journal

LII Article views: 392 


\section{EDITORIAL}

\section{When to stop?}

Duration and discontinuation of treatment are essential issues in drug prescribing. General practitioners (GPs) have to decide on the length of the therapy when writing a prescription and also have the responsibility to inform patients accordingly.

In Western countries, an increasing number of therapeutic drug groups are primarily prescribed by the GP [1-3]. Prescription data collected at a national level in Denmark in 2001-2005 [4] showed that more than $90 \%$ are dispensed by pharmacies servicing the primary health sector. A fraction of these treatments may have been initiated by hospital clinics or specialists, but the continued control of the treatments is largely the responsibility of the GP. Sometimes an ongoing treatment may prove not to be appropriate any more regardless of the time and place of initiation $[5,6]$. The decision to stop treatment most often has to be taken by the GP. If unnecessary treatments are continued it may lead to for example polypharmacy, side effects and unnecessary expense.

Optimal decisions on duration and discontinuation of drug therapies require that the GP has access to relevant and precise information on the subject. This information should in principle be evidencebased, i.e. founded on scientific data from randomized controlled trials. One might expect such information to be an integral part of national and international textbooks dealing with drug therapies as well as review articles and guidelines in the different fields of therapeutics. However, in many fields of drug therapy explicit recommendations concerning duration of therapy based on appropriate scientific documentation appear to be sparse or nonexistent. Therefore we decided to examine the problem more systematically.

We evaluated the recommendations given in six internationally well-reputed textbooks dealing with drug therapy: three textbooks on clinical medicine [7-9], two textbooks on clinical pharmacology and therapeutics [10,11], and one book with review articles on evidence for existing therapies in healthcare [12].

Each book was assessed with regard to recommendations given for some of the drugs typically initiated in general practice (Table I). For a classification of the recommendations given concerning duration and treatment, six categories were defined:

A. No text on drug/indication.

B. No mention of time limitations or optimal duration of therapy.

C. Mention of possible time limitation, but no mention of optimal length of therapy, or only vague suggestions. Included mention of possible long-term adverse effects, drug dependence, loss of effect, etc.

D. Specific recommendations for duration of therapy.

E. Specific indication that the drug therapy is considered lifelong.

F. Diagnostic discontinuation: Indication that therapy usually is lifelong, but that discontinuation may be recommendable to exclude false indication or recovery.

The evaluations were carried out by two of the authors. Divergences were resolved through discussion with the third author. We found good agreement on the ratings and all differences were small and easily resolved by re-examinations of the texts and discussion.

Table I shows the number of books for each scoring category (A-F). There was generally good agreement between the different books on the scoring for each drug/indication. Analyses of ratings for individual books revealed no consistent differences between books or types of books (clinical medicine vs. clinical pharmacology and therapeutics). Apart from being short of two of the evaluated drug/indications (score: A), BMJ Clinical Evidence [6] did not differ significantly from the other books.

Specific recommendation on duration (score D) was only a general feature for a few drug treatments/ indications: anti-ulcer therapy largely linked to the Helicobacter pylori eradication scheme, antimycotics, antibiotics, anti-viral therapy, and antidepressants.

For drug-treatment/indications generally considered lifelong we only found one example in one textbook where this was explicitly indicated and in one other case diagnostic discontinuation was suggested. 
Table I. Drug therapy initiated in general practice: Textbook recommendations on duration and discontinuation of therapy.

\begin{tabular}{|c|c|c|c|c|c|c|c|c|}
\hline \multirow[b]{2}{*}{ ATC codes } & \multirow[b]{2}{*}{ Drug groups } & \multicolumn{6}{|c|}{ Recommendations } & \multirow[b]{2}{*}{ Indications } \\
\hline & & A & $\mathrm{B}$ & $\mathrm{C}$ & $\mathrm{D}$ & $\mathrm{E}$ & $\mathrm{F}$ & \\
\hline $\mathrm{A} 02 \mathrm{BA}+\mathrm{C}$ & $\begin{array}{l}\mathrm{H} 2 \text {-receptor antagonists } \\
\text { and proton pump inhibitors }\end{array}$ & 1 & 1 & 1 & 3 & & & Dyspepsia \\
\hline A08 & Anti-obesity drugs & & 2 & 3 & 1 & & & Overweight \\
\hline A10A & Insulin & & 4 & 2 & & & & DM, type $1 \& 2$ \\
\hline A10B & Oral antidiabetics & & 4 & 2 & & & & DM type $1 \& 2$ \\
\hline $\mathrm{C} 01 \mathrm{~A}$ & Digoxin & & 5 & 1 & & & & Cardiac failure, arrhythmia \\
\hline C01D & Nitrates & & 6 & & & & & Coronary syndrome \\
\hline $\mathrm{C} 03+07+08+09 \mathrm{~A}+\mathrm{C}$ & Antihypertensives $^{1}$ & & 5 & & & & 1 & Hypertension \\
\hline C10AA & Statins & & 5 & & & 1 & & Hypercholesterol \\
\hline $\mathrm{C} 10 \mathrm{AB}$ & Fibrates & & 6 & & & & & Hypercholesterol \\
\hline D01A & Antimycotics (derm.) & & & 1 & 5 & & & Dermal fungal infection \\
\hline D07 & Glucocorticoids (derm.) & & 3 & 3 & & & & Dermatitis/eczema \\
\hline G03A & Oral contraceptives & 1 & 4 & 1 & & & & Contraception \\
\hline $\mathrm{G} 03 \mathrm{C}+\mathrm{D}+\mathrm{F}$ & Estrogen and/or progestogen & & 4 & & 2 & & & Bleeding disorder \\
\hline $\mathrm{H} 02 \mathrm{~A}$ & Glucocorticoids (systemic) & & 1 & 5 & & & & Anti-inflammatory \\
\hline J01 & Antibiotics & & & 1 & 5 & & & Several infections \\
\hline J05 & Antivirals & & 1 & 2 & 3 & & & Influenza, herpes simplex/zoster \\
\hline M01A & NSAIDs & & 6 & & & & & Anti-inflammatory \\
\hline N02A & Opioids & & 4 & 2 & & & & Severe pain \\
\hline N02C & Anti-migraine drugs & & 6 & & & & & Migraine \\
\hline $\mathrm{N} 05 \mathrm{~B}+\mathrm{C}$ & Anxiolytics/hypnotics & & 1 & 4 & 1 & & & Anxiety, sleep disturbances \\
\hline N06 & Antidepressants & & 1 & 1 & 4 & & & Depression, acute \\
\hline R03 & Anti-asthma drugs & & 1 & 5 & & & & Asthma \\
\hline R06 & Antihistamines (systemic) & & 6 & & & & & Allergic reactions \\
\hline
\end{tabular}

Notes: ${ }^{1}$ Diuretics, betablockers, Ca antagonists, ACE inhibitors, Ang. tens. II inhibitors (five books only).

Recommendations - as given in the six reviewed books (see text): A: No text on drug/indication; B: No mention of time limitations or optimal duration of therapy; C: Mention of possible time limitations, but no mention of optimal length of therapy, or only vague suggestions; D: Specific recommendations for duration of therapy; E: Specific indication that the therapy is considered lifelong; F: Diagnostic discontinuation: Indication that therapy usually is lifelong, but that discontinuation may be recommendable to exclude false indication or recovery.

Numbers in italics indicate the number of books with the given recommendation score (A-F).

Explicit discussion of the treatment's duration was with a few exceptions only found for short-term regimens and nearly absent for therapies generally considered "chronic". The textbooks investigated were selected on the basis of their general, international esteem and popularity, but the selection was indeed subjective. Other textbooks, international or national, could have a more practical approach to drug treatment per se and therefore give more specific advice. However, the homogeneity in our findings between the different books investigated was striking and supports the view that the results may be generalizable.

The presence or absence of specific recommendations may reflect the level of underlying clinical evidence as typically obtained from randomized controlled trials (RCTs). The frequent, specific recommendations for antimicrobial treatments may thus reflect the fact that duration of treatment is often an explicitly tested variable in RCTs in this field [13-16]. On the other hand, duration of treatment has not been addressed as a primary variable in RCTs on antisecretory medication if
Helicobacter pylori eradication schemes are disregarded and classified as antibiotic treatment [1720]. For antidepressants four out of six textbooks gave specific recommendations on duration despite the fact that a literature search yielded only one original study with duration of treatment as a primary variable [21]. The recommendations given in the literature appear generally to be based on theoretical and clinical considerations [22-24].

As to the presumed "lifelong" treatments, such as lipid-lowering drugs, the general, often implicit recommendation in the literature is that once started the treatment should be lifelong, although little or no direct, hard evidence for the appropriateness of this strategy exists [25-28]. The inclusion of duration as a primary variable in RCTs on presumed lifelong treatments (lipid-lowering drugs, antihypertensives, antidiabetics, antiepileptics, etc.) may pose insurmountable clinical and ethical problems. The evidence must therefore often be sought from less strong data, such as observational studies, epidemiological research etc. However, discontinuation may prove to be possible [29]. 
It is our opinion that duration of drug therapy has received relatively little attention in the relevant literature, from RCTs to major textbooks. However, for the GP, with the primary responsibility for the vast majority of drug therapies, guidance concerning duration and discontinuation of drug treatment is indispensable. We hope more attention is paid to this issue in the future at all levels: the conduct of RCTs, meta-analyses, reviews, textbooks, guidelines, and regulatory.

\section{fon Eik Zwisler, MD PhD \\ Research Unit for General Practice and Department of Medical Gastroenterology University of Southern Denmark Fohn Larsen \\ Research Unit for General Practice University of Southern Denmark Lars F. Gram Research Unit of Clinical Pharmacology University of Southern Denmark}

\section{References}

[1] Silwer L, Johansson E, Stalsby LC. Drug prescribing in public primary care centres: Results from prescription studies 1988-1997 in the county of Halland, Sweden. Scand J Prim Health Care 2000;20:236-41.

[2] Gaist D. Use and overuse of sumatriptan: Pharmacoepidemiological studies based on prescription register and interview data. Cephalalgia 1999;19:735-61.

[3] EURO-MED-STAT. Monitoring expenditure and utilization of medicinal products in the European Union countries: A public health approach. Eur J Public Health 2003;13:95100.

[4] Annual Statistics. Danish Medicines Agency; 2007. Available at: http://dkma.medstat.dk/MedStatDataViewer.php.

[5] Brekke M, Rognstad S, Straand J, Furu K, Gjelstad S, Bjørner T, et al. Pharmacologically inappropriate prescriptions for elderly patients in general practice: How common? Scand J Prim Health Care 2008;26:80-5.

[6] Johnell K, Fastbom J. Multi-dose drug dispensing and inappropriate drug use: A nationwide register-based study of over 700,000 elderly. Scand J Prim Health Care 2008;26: $86-91$.

[7] Oxford Textbook of Medicine. 4th ed. Oxford: Oxford University Press; 2003.

[8] Harrison's Principles of Internal Medicine. 16th ed. New York: McGraw-Hill; 2004.

[9] Cecil Textbook of Internal Medicine. 22nd ed. Philadelphia: WB Saunders; 2004.

[10] Avery's Drug Treatment. 4th ed. Auckland: Maclennan \& Petty; 1997.

[11] Goodman and Gilman's pharmacological basis for therapies. 11 th ed. New York: McGraw-Hill; 2005.

[12] Clinical evidence. 2006 ed. London: BMJ Publishing Group; 2006.

[13] Cohen R, Levy C, Boucherat M, Langue J, de La RF. A multicenter, randomized, double-blind trial of 5 versus 10 days of antibiotic therapy for acute otitis media in young children. J Pediatr 1998;133:634-9.
[14] Benador D, Neuhaus TJ, Papazyan JP, Willi UV, Engel-Bicik I, Nadal D, et al. Randomised controlled trial of three day versus 10 day intravenous antibiotics in acute pyelonephritis: Effect on renal scarring. Arch Dis Child 2001;84:241-6.

[15] East and Central African/British Medical Research Council. Controlled clinical trial of 4 short-course regimens of chemotherapy (three 6-month and one 8-month) for pulmonary tuberculosis. Tubercle 1983;64:153-66.

[16] Joesoef MR, Schmid GP. Bacterial vaginosis: Review of treatment options and potential clinical indications for therapy. Clin Infect Dis 1995;20:S72-9.

[17] Van Soest EM, Siersema PD, Dieleman JP, Sturkenboom MCJM, Kuipers EJ. Persistence and adherence to proton pump inhibitors in daily clinical practice. Aliment Pharmacol Ther 2006;24:377-85.

[18] Bjornsson E, Abrahamsson H, Simren M, Mattsson N, Jensen C, Agerforz P, et al. Discontinuation of proton pump inhibitors in patients on long-term therapy: A double-blind, placebo-controlled trial. Aliment Pharmacol Ther 2006;24: 945-54.

[19] Donnellan C, Sharma N, Preston C, Moayyedi P. Medical treatments for the maintenance therapy of reflux oesophagitis and endoscopic negative reflux disease. Cochrane Database Syst Rev 2005;(2):CD003245.

[20] Inadomi JM, Jamal R, Murata GH, Hoffman RM, Lavezo LA, Vigil JM, et al. Step-down management of gastroesophageal reflux disease. Gastroenterology 2001;121:1095100.

[21] Reimherr FW, Amsterdam JD, Quitkin FM, Rosenbaum JF, Fava $M$, Zajecka J, et al. Optimal length of continuation therapy in depression: A prospective assessment during longterm fluoxetine treatment. Am J Psychiatry 1998;155:124753.

[22] Viguera AC, Baldessarini RJ, Friedberg J. Discontinuing antidepressant treatment in major depression. Harv Rev Psychiatry 1998;5:293-306.

[23] Geddes JR, Carney SM, Davies C, Furukawa TA, Kupfer DJ, Frank E, et al. Relapse prevention with antidepressant drug treatment in depressive disorders: A systematic review. Lancet 2003;361:653-61.

[24] Angst J. Fortnightly review. A regular review of the longterm follow up of depression. Br Med J 1997;315:1143-6.

[25] Randomised trial of cholesterol lowering in 4444 patients with coronary heart disease: The Scandinavian Simvastatin Survival Study (4S). Lancet 1994;344:1383-9.

[26] Prevention of cardiovascular events and death with pravastatin in patients with coronary heart disease and a broad range of initial cholesterol levels. The Long-Term Intervention with Pravastatin in Ischaemic Disease (LIPID) Study Group. N Engl J Med 1998;339:1349-57.

[27] Sever PS, Dahlof B, Poulter NR, Wedel H, Beevers G, Caulfield $M$, et al. Prevention of coronary and stroke events with atorvastatin in hypertensive patients who have average or lower-than-average cholesterol concentrations, in the Anglo-Scandinavian Cardiac Outcomes Trial-Lipid Lowering Arm (ASCOT-LLA): A multicentre randomised controlled trial. Lancet 2003;361:1149-58.

[28] Wei L, Ebrahim S, Bartlett C, Davey PD, Sullivan FM, MacDonald TM. Statin use in the secondary prevention of coronary heart disease in primary care: Cohort study and comparison of inclusion and outcome with patients in randomised trials. Br Med J 2005;330:821.

[29] Gorgels W, Oude Voshaar R, Mol A, Van De Lisdonk E, Mulder J, Van Den Hoogen $\mathrm{H}$, et al. A benzodiazepine discontinuation programme does not increase the frequency of contacts with the family practice. Scand J Prim Health Care 2008;26:74-9. 